\title{
Effect of Adding Black Rice Flour on Properties of Processed Cheese Spread
}

Meranda A.Tawfek

Dairy Sci.\&Technol. Res.,Dept. Food Technol. Res. Inst., Agricultural Research Center, Giza, Egypt

$\mathbf{T}$

HE effect of adding black rice flour (oryza sativa L. indica) (BRF) on properties of spread type processed cheese (STPC) was the aim of this study. BRF contained rich amount of antioxidants (anthocyanin's, total phenols and total flavonoids), protein, crude fiber, total carbohydrates and minerals.

Six treatments of STPC were performed by substituting cheese-base with BRF at the ratio of (the control) nil, 5,10,15,20 and $25 \%$ on the dry basis. Chemical composition and Organoleptic properties were determined after processing and during storage periods for three months.

Significant differences $\mathrm{p}>0.05$ were found between STPC treatments as affected by the substitution ratio of BRF. The results showed that the BRF contained anthocyanin's (4874.8 mg cy-3- glc/100gm dry weight), total phenols (695.4mg GAE/100 gm dry weight), total flavonoids (112.6mg quarstine/100 gm dry weight) and DPPH (76.85\%). Although DM, fat/ $\mathrm{DM}$ and ash/DM contents of STPC were not influenced by adding BRF, the total nitrogen (TN)/ DM percentage significantly tended to decrease when the level of cheese-base substitution with BRF exceeded $25 \%$. The soluble nitrogen (SN)/TN percentage of all treatments of STPC was higher than that of the mature Ras cheese itself, used as cheese-base, and decreased significantly as the portion of BRF instead of cheese-base increased. The gradual substitution of cheesebase with BRF in STPC making was associated with the proportional increment in the fibers/ DM percentage and decrement in the titratable acidity $\%$, in spite of the stability of $\mathrm{pH}$ value at 5.8. Hardness, cohesiveness, gumminess and chewiness exhibited proportionally higher values, while, springiness property behaved opposite trends as the BRF was used instead of cheese-base in STPC recipes. Whether, the proportional replacement of cheese-base with BRF or the prolonging of cold storage period was associated with the gradual increase in the oil separation index and decrease in the meltability \% as well as in the penetration ( $\mathrm{mm}$ ) of STPC. The use of BRF instead of cheese-base did not lead to any significant differences in the score of all organoleptic attributes of STPC. Moreover, the BRF flavour was accepted and favorably preferred in STPC and improved the stability of sensory quality of STPC along the cold storage period, especially when the substitution level of cheese-base with BRF was more than 5\%.The blends prepared by using $5,10,15$, and $20 \%$ BRF showed higher acceptability compared to the control or $25 \%$ blend.

Keywords: Black rice flour (BRF), Spread type processed cheese (STPC), Texture profile, Physical properties.

\section{Introduction}

Processed cheese are among cheese verities appreciated by consumers, whereas, they are considered the main daily sandwich filling food for school children or even for adults. The Egyptian dairy industry produces about thousand ton per year (CFI, 2015). Processed cheese is made by blending natural cheeses of different ages, degrees of maturity and sources, adding water, colouring agents and emulsifying salts and then heating and agitating until a homogenous mixture is produced. The naturally matured cheese contains partially hydrolyzed casein as well as flavouring source (maximum $20 \%$ of total blend protein). The blend contains fresh and moderate cheese curd as a source of intact casein (minimum $50 \%$ of total protein for spreadable type and $70 \%$ of block one). The final product has a consistency 
suitable for packaging, and can be stored at or near room temperature for long periods. (Mayer, 1973, Thomas, 1977, Berger et al., 1989, Caric \& Kalab, 1993, Fox et al., 2000, AbdEl-Salam et al., 2005 and Mahran et al., 2007).

Foods ingredients or flavourings can be added to processed cheese to obtain a particular flavour, to enhance or modify its flavour, or to make the cheese more attractive. They include sausages, meat, ham, salami, salmon, wines, fruit, coffee or chocolate, tomato, celery, parsley, chives, caraway seed, onions, mushroom, Jerusalem artichoke and truffle fungi powder (Thomas, 1977, Fayed et al., 2009 and Awad et al., 2014). Rice (oryza sativa L.) is a widely consumed food source for over half of the world's population. There are many special cultivars of rice that contain colour pigments, such as black, red and brown. However, in the recent years pigmented rice varieties have received increased attention from the researchers and consumer preferences have shifted towards pigmented types having high nutritional properties (Li et al., 2016). Many people assume this rice as a panacea of many culinary diseases because of its high nutritive value and curative effect. This rice is supposed to enhance the longevity of life; hence it is also known as long life rice (Kong and Lee, 2010). Rice plays an important role in meeting the needs of humans for vitamins and minerals and it has a relatively high content of nutrient per unit of energy. There are many different kinds of rice, including white rice and a variety of coloured rice. Rice with coloured hulls has long been considered to be a healthy food. Reports have shown that supplementation of diets with black rice pigments markedly reduced atherosclerotic. Black rice pigments are mainly located in the aleurone layer, which is characterized as dark purple to black in colour and probably represents a mixture of anthocyanin's (Ling et al., 2002).

Black rice (oryza sativa L. indica) is one of the most potential plant sources of dark purple colour of anthocyanin's pigment. The black rice kernel contains high level of bioactive compounds such as $\gamma$-oryzanol, anthocyanin's and phenolic compounds. A number of studies showed that these compounds can reduce low-density lipoprotein cholesterol (LDL), improve lipid profiles, have anti-inflammatory and antioxidative activities, may help to fight heart disease, and prevent diabetes (Guo et al., 2007).

In addition, black and red rice cultivars are popular in Asia, where consumed for nutritional colour and unique flavour attributes for example; black and red rice are used as food colourants in cakes, breads, ice cream, ice milk and liquor and as functional foods due to the antioxidant activity conferred by high levels of polyphenols (AbdelAal et al., 2006 and Tawfek et al., 2017). Black rice has a higher content of protein, vitamins and minerals, although the latter varies with cultivar and production location (Suzuki et al., 2004). Black rice outer layer fraction (rice extract) is a good source of dietary fiber, oil, flavonoids, polyphenols and anthocyanidins. The pigment from black rice contains two major anthocyanins: cyanidin-3-glucoside and peonidine-3-glucoside (Hu et al., 2003). Anthocyanins can decrease the risk of coronary heart disease; inflammatory activities (Hu et al., 2003, Xia et al., 2003 and Ling et al., 2001) found that a hybercholesterolemic diet containing black rice did not alter plasma T.G.levels in rabbits. Peonidin, peonidin3glucoside and cyanidin3-glucoside which the major anthocyanins extracted from black rice exerted an inhibitory effect of cell invasion on various cancer cells (Chen et al., 2006)

The objective of this investigation was to produce STPC using BRF as substitution component of cheese-base, also, study the effect of this substitution on chemical, physicochemical and organoleptic properties of produced cheese.

\section{Materials and Methods}

\section{Materials}

Cheese-bas were purchased from the local market, Cairo, Egypt. Cooking salt produced by El-Nasr Saline>s Company. Commercial melting Joha S9s emulsifying salt special. Black rice (Oryze sativa L. indica) (BRF) was obtained from Rice Research and Training Center (RRTC) at Sakha, Experimental Station Kafr El-Sheikh Governorate , Egypt during the season of 2016. The composition of dairy ingredients used is presented in Table 1. 
TABLE 1. Gross composition of Ras cheese-base and black rice flour(BRF)used in formulation of spread type processed cheese(STPC).

\begin{tabular}{|c|c|c|c|}
\hline \multirow{3}{*}{ Component } & \multicolumn{3}{|c|}{ Ingredients } \\
\hline & \multicolumn{2}{|c|}{ Ras cheese-base } & \multirow{2}{*}{$\begin{array}{l}\text { Black rice flour } \\
\text { (BRF) }\end{array}$} \\
\hline & Mature & Fresh & \\
\hline Dry matter (DM)\% & 65.22 & 54.90 & 88.76 \\
\hline Total nitrogen(TN/DM)\% & 5.30 & 3.24 & 9.24 \\
\hline Fat/DM\% & 30.95 & 26.10 & 2.59 \\
\hline Carbohydrate/DM\% & 0.96 & 1.90 & 83.66 \\
\hline Fibers/DM\% & - & - & 2.59 \\
\hline $\mathrm{Ash} / \mathrm{DM} \%$ & 8.50 & 7.90 & 1.92 \\
\hline Soluble nitrogen/TN\% & 25.78 & 22.95 & 8.50 \\
\hline Anthocyanin's mg cy-3-glc/100g dw. & - & - & 4874.8 \\
\hline Total phenol mg GAE/100g dw. & - & - & 695.4 \\
\hline Total flavonoids mg quartine $/ 100 \mathrm{~g} \mathrm{dw}$ & - & - & 112.6 \\
\hline Antioxidant activity $*(\mathrm{DPPH}) \%$ & ND & ND & 76.85 \\
\hline
\end{tabular}

*Reduction percentage of antioxidant activity of DPPH

DPPH: 2,2 diphenyl-1-picrichydrazyl.

ND: not determined.

\section{Experimental Procedures}

\section{Preparation of black rice flour (BRF)}

Raw rice grain samples were milled to obtain the black rice flour (BRF) which could pass through a 60-80 mesh screen. The resultant flour was packed in polyethylene bags and stored in refrigerator until used. The composition of the resultant BRF and other ingredients used in processed cheese are presented in Table 1.

Manufacture of processed cheese with black rice flour (BRF)

Processed cheese was made using cheesebase and BRF in formulating the base blend were used for the experimental processed cheese at suitable level as recommended by Meyer (1973). BRFat the ratio of (the control) nil,5,10,15,20,25 and 30\%. Melting salt (S9s emulsifying salt special) was added at the level of $2.5 \%$ (Joha $\mathrm{SE})$. Furthermore, the $\mathrm{pH}$ value of all blends was adjusted to 5.8 as recommended by Meyer (1973) using $10 \%$ citric acid $(\mathrm{CH} 3 \mathrm{COOH})$ or $\mathrm{NaHco}_{3}$ solution. The preparations of the initial ingredients and cooking procedure were carried out as described by Meyer $(1973)$ at $85^{\circ} \mathrm{C}$ for 7 min using indirect steam at pressure $2-2.5 \mathrm{Kg} / \mathrm{cm}^{2}$ using a double jacket pan with a batch capacity of $2.0 \mathrm{Kg}$ and stirring velocity of 120-140 r.p.m. The resultant cheese were filed into glass jars, airtightly closed and analyzed when fresh, and after 1,2 and 3 months during storage at refrigerator $\left(5 \pm 1^{\circ} \mathrm{C}\right)$. The composition of different formulations used is shown in Table 2. Three replicates were carried out for each processed cheese treatment.

TABLE 2. Composition of different blend formulas $(\mathrm{Kg} / 100 \mathrm{Kg})$ used in manufacture of spread type processed cheese (STPC) with different ratioof black rice flour (BRF) in the base bland.

\begin{tabular}{lllllll}
\hline $\begin{array}{l}\text { Ingredient } \\
(\%) \text { DM }\end{array}$ & $\begin{array}{c}\text { (control) } \\
\text { Nil }\end{array}$ & $\mathbf{5}$ & $\mathbf{1 0}$ & $\mathbf{1 5}$ & $\mathbf{2 0}$ & $\mathbf{2 5}$ \\
\hline Cheese-base : & & & & & & \\
$\quad$ Mature (65\%) & 12.5 & 11.25 & 10 & 8.74 & 7.5 & 6.25 \\
$\quad$ Fresh (55\%) & 44.32 & 42.85 & 41.36 & 39.89 & 38.41 & 36.93 \\
$\quad-$ & 1.83 & 3.65 & 5.48 & 7.31 & 9.13 \\
BRF (89\%) & 2.5 & 2.5 & 2.5 & 2.5 & 2.5 & 2.5 \\
Emulsifying salt & 40.68 & 41.57 & 42.49 & 43.39 & 44.28 & 45.19 \\
Water & 100 & 100 & 100 & 100 & 100 & \\
Total & & & & & & \\
\end{tabular}




\section{Analytical methods}

Chemicalanalyses

Contents of dry matter (DM), total nitrogen $(\mathrm{TN})$, fat, crude fibers and ash were determined as reported by AOAC (2007). Titratable acidity as lactic acid (TA), total and water soluble nitrogen (SN) contents were determined as given by Ling (1963).Total carbohydrates were calculated by difference. Total anthocyanin's pigments content of the rice samples was determined, according to the modified $\mathrm{pH}$ differential methods of Giusti and Wrolsted (2005) and Hosseinian et al. (2008). Total phenols were estimated by the Folin- Ciocalteu method reported by Elfallehet al. (2009). The amount of total flavonoids was according to the method of Nasriet al. (2011). The DPPH (2,2 diphenyl-1-picrichydrazyl) radical scavenging activity of methanolic extracts was determined according to the method reported by Okonogi et al. (2007).

\section{Physicochemical analysis}

The $\mathrm{pH}$ value was measured electrometrically in lab using a digital pH meter "HANNA", with combined glass electrode (Electric Instruments Limited). Likewise, penetration value was measured as described by Bourne (1982). Oil separation index was determined according to Thomas (1973). Meltability was measured using the meltability test apparatus as described by Karan and Ak (2003).

\section{Textrural profile analysis (TPA)}

Texture profile of STPC was measured at $23^{\circ} \mathrm{C}$ as described by Bourne (1982) using an Instron Universal Testing Machine model 1195, Stable Micro System (SMS) Ltd., Godalming, UK, loaded with Dimension Software SMS program.

\section{Sensory evaluation}

Organoleptic properties of STPC samples were evaluated by 10 panel members of the Dairy Sci. Dept. Fac. Of Agric. Cairo and Ain shams Universities for flavour\& aroma (40 points), body $\&$ texture (40 points) and appearance \& colour (20 points) as reported by Meyer (1973).

\section{Statistical analysis}

The obtained data were statistically analyzed according to Statistical Analyses System user>S guide (SAS, 1998).

\section{Results and Discussion}

At the beginning of the study, the cheese-base was replaced with black rice flour (BRF) by the Egypt. J. Food Sci. 46 (2018) ratio of nil (the control), 5, 10, 15, 20, 25 and $30 \%$. The sensory evaluation analysis was done at the beginning of the study and the results were as follows: treatments nil (the control), 5, 10, 15,20 , and $25 \%$ that the data given me order of sensory evaluation degrees. While the treatment excluded by replacing $30 \%$ cheese-base with BRF was totally rejected. Therefore, it was considered that the research will include nil (the control), $5,10,15,20$, and $25 \%$ treatments by replacing the cheese-base with the BRF and the required analyses will be carried out during the period of storage at $5 \pm 1^{\circ} \mathrm{C}$.

\section{Chemical properties}

The chemical composition of spread type processed cheese (STPC) with BRF is presented in Table 3. Total solid and fat contents in all processed treatments were in a narrow range and showed very close values. This was expected since all ingredients were adjusted in the formula before the cooking process. The slight differences among treatments could be due to the differences in the individual ingredients weight used in formulating the processed cheese bland. Control treatment without BRF possessed the highest content of soluble nitrogen/TN. Data displayed in Table 3 show that, the previous adjustment of the contents of dry matter at $36 \%$ as well as the fat/DM at $35 \%$ of the recipes of STPC led to gain non-significant differences in both criteria among all treatments. Likewise, the ash/DM content of STPC showed non significant differences between samples in STPS with the ratio of BRF. Whereas, the TN/DM content tended significantly to decrease when the ratio of BRF exceeded $20 \%$; addition of $25 \%$ BRF resulted in highest fibers and ash contents in the resultant processed cheese. The highest contents of fibers and ash in STPC with BRF are mainly due to the highest contents of these components in BRF, compared with cheese-base (Table 1). As well known, the dairy ingredients used never contain any dietary fibers, therefore BRF is considered as a dietary fiber source and consequently the gradual incrementof BRF ratio was associated with significantly proportional increase in the fibers/DM content of STPC.

Moreover, it is worthy to mention that, the SN/ TN content of STPC was higher even than that of the cheese-base itself, from which it was made. This phenomena may be attributed to the action of the melting salt added, which worked to dissociate the protein-protein interactions. These results 
are in agreement with those found by Abd elHamid et al. (2000). Among treatments, the SN/ TN content of STPC decreased significantly as the portion of BRF instead of the part in cheesebase increased. This may be due to the relatively low SN/TN content of BRF versus that of the part in cheese-base (Table 1).

The results in Table 3 revealed that anthocyanin's of STPC with BRF ratios (control) nil, 5, 10, 15, 20 and 25\% were 00.00, 243.70, $477.50,730.20,811.10$ and 920.22 (mg cy-3$\mathrm{glc} / 100 \mathrm{~g} \mathrm{dw})$, respectively. On the other hand the anthocyanin's contents of STPC were slightly increased with BRF ratios 20 and $25 \%$. Data in the same table also showed that total phenols, total flavonoids and DPPH were slightly increased with BRF ratios 20 and 25\%. Total phenols, total flavonoids and DPPH recorded values 98.50, 30.50 and 20.72 , respectively at the ratio $25 \%$ of BRF.

Titratable acidity \% (TA) and $\mathrm{pH}$ value

Replacing cheese-base with BRF in the base blend lowered slightly the TA values of STPC with all treatments compared to the control cheese. Figure 1 shows that, although the designed $\mathrm{pH}$ value, at which STPC recipes were cooked, remained unchanged at 5.8. The titratable acidity \% of resultant STPC showed a significantly proportional reduction as the portion of BRF increased. This phenomenon may be due to the buffering compounds in the STPC such as protein and the added melting salts as BRF don't affect $\mathrm{pH}$ and titratable acidity. The $\mathrm{pH}$ values of resultant cheese are shown in Fig. 2.

TABLE 3. Chemical properties of STPC with different ratios of BRF in the base blend.

\begin{tabular}{|c|c|c|c|c|c|c|}
\hline \multirow{2}{*}{ Character assessed } & \multirow{2}{*}{ (control) Nil } & \multicolumn{5}{|c|}{ Ratio (\%) of BRF } \\
\hline & & 5 & 10 & 15 & 20 & 25 \\
\hline Dry matter (DM)\% & $36.03^{\mathrm{a}}$ & $30.99^{\mathrm{a}}$ & $30.97^{\mathrm{a}}$ & $30.95^{\mathrm{a}}$ & $30.94^{\mathrm{a}}$ & $30.96^{\mathrm{a}}$ \\
\hline Fat/DM\% & $35.00^{\mathrm{a}}$ & $35.01^{\mathrm{a}}$ & $35.03^{\mathrm{a}}$ & $35.05^{\mathrm{a}}$ & $35.06^{\mathrm{a}}$ & $35.01^{\mathrm{a}}$ \\
\hline Total nitrogen(TN)/DM\% & $5.737^{\mathrm{a}}$ & $5.735^{\mathrm{a}}$ & $5.734^{\mathrm{a}}$ & $5.731^{\mathrm{a}}$ & $5.730^{\mathrm{a}}$ & $5.720^{b}$ \\
\hline Fibers/DM\% & $0.000^{\mathrm{d}}$ & $0.050^{\mathrm{c}}$ & $0.090^{c}$ & $0.150^{\mathrm{b}}$ & $0.190^{\mathrm{b}}$ & $0.230^{\mathrm{a}}$ \\
\hline $\mathrm{Ash} / \mathrm{DM} \%$ & $20.11^{\mathrm{a}}$ & $20.12^{\mathrm{a}}$ & $20.12^{\mathrm{a}}$ & $20.13^{\mathrm{a}}$ & $20.15^{\mathrm{a}}$ & $20.15^{\mathrm{a}}$ \\
\hline Soluble nitrogen/TN\% & $66.299^{\mathrm{a}}$ & $65.760^{\mathrm{a}}$ & $63.360^{\mathrm{b}}$ & $60.891^{\mathrm{b}}$ & $59.570^{c}$ & $57.580^{c}$ \\
\hline Anthocyanin's & $00.00^{\mathrm{d}}$ & $243.70^{\mathrm{c}}$ & $477.50^{\mathrm{b}}$ & $730.20^{\mathrm{b}}$ & $811.10^{\mathrm{a}}$ & $920.22^{\mathrm{a}}$ \\
\hline Total phenols & $00.00^{\mathrm{d}}$ & $30.60^{c}$ & $69.93^{\mathrm{b}}$ & $75.87^{\mathrm{b}}$ & $89.91^{\mathrm{a}}$ & $98.50^{\mathrm{a}}$ \\
\hline Total flavonoids & $00.00^{\mathrm{d}}$ & $9.77^{\mathrm{c}}$ & $19.88^{b}$ & $21.50^{\mathrm{b}}$ & $26.99^{a}$ & $30.50^{\mathrm{a}}$ \\
\hline DPPH \% & $00.00^{\mathrm{d}}$ & $4.84^{\mathrm{c}}$ & $8.68^{\mathrm{b}}$ & $10.12^{\mathrm{b}}$ & $17.93^{\mathrm{a}}$ & $20.72^{\mathrm{a}}$ \\
\hline
\end{tabular}

The means with the same letter did not significantly differ $(\mathrm{P}>0.05)$,

DPPH: 2,2 diphenyl-1-picrichydrazyl

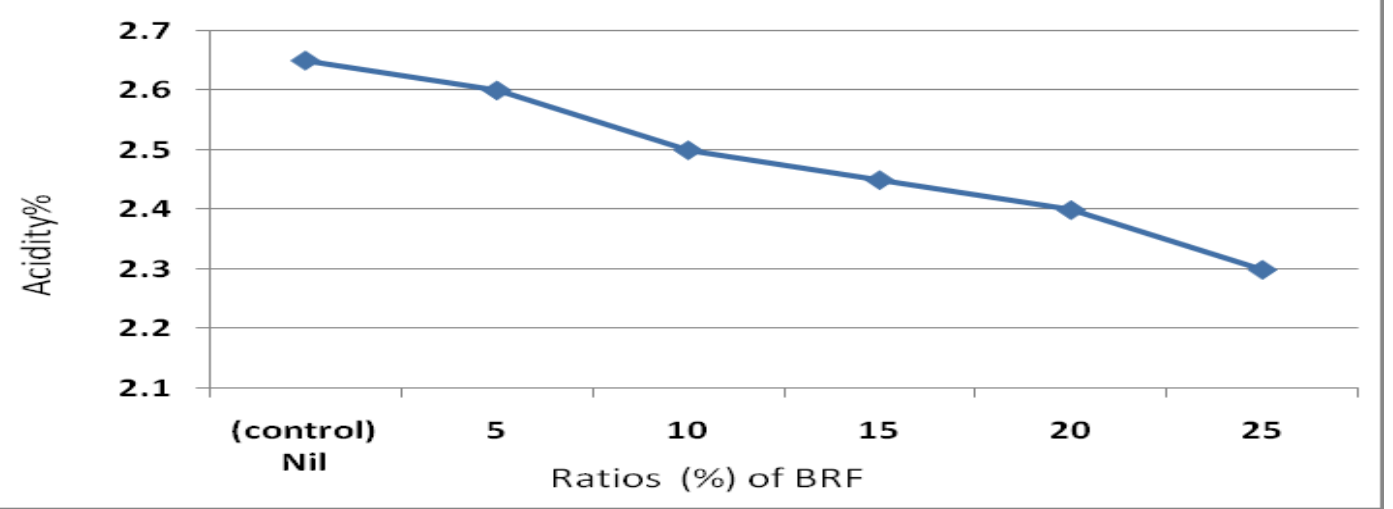

Fig.1.Titratable acidity\% of fresh STPC as affected by using different ratios of BRF. 




Fig. 2. pH values of fresh STPC as affected by using different ratios of BRF.

\section{Texture profile analysis (TPA)}

The textural properties parameters of STPC samples with different ratio of BRF in the base bland when fresh are shown in data illustrated in Table 4. Obtained data indicate that, except the springiness criterion, other texture parameters, namely hardness, cohesiveness, gumminess and chewiness exhibited significantly proportionally higher values, i.e. the texture of STPS became harder,more gummy and chewy as the BRF was increased in the base blend. These observations may be explained with regard to the $\mathrm{SN} /$ TN content of STPC. However, the hardness, cohesiveness, gumminess and chewiness followed a reverse direction trend with SN level. Similar findings were reported by Pollard et al. (2003) and Fox et al. (2000). Moreover, springiness property of STPC behaved in opposite trends towards the $\mathrm{SN} / \mathrm{TN}$ content and this does not change in the product during cold storage period.

\section{Physical properties}

The results in Table 5 indicate the common physical properties, namely, the penetration $(\mathrm{mm})$, oil separation index and meltability $\%$ of STPC samples with different ratio of BRF in the base blend and the effect of the cold storage period (CSP) for 3 months. Obtained data demonstrate that, like what happened with the hardness, the penetration $(\mathrm{mm})$ values was significantly strengthened as the manufacture of cheese-base with ratio (\%) of BRF. Moreover, gradual increases in the oil separation index of
STPC were recorded in relation to the prolonging of cold storage period. This phenomenon may be attributed to the interaction of the melting salts with the protein as well as the decrease in acidity $\%$ during storage caused by the changes in the form of melting salts. The results agree with the findings of Tamime et al. (1990), Younis et al. (1991) and Awad \& Salama (2010b).

Regarding the oil separation index of STPC, data indicate that, both the proportional manufacture of cheese-base with ratio (\%) of $\mathrm{BRF}$ and the prolonging of cold storage period were associated with gradual weakness in the fat emulsion, i.e. increase in the oil separation. This means that, the emulsion capacity of BRF protein was lower than that of cheesebase protein. Likewise, the increment in $\mathrm{SN}$ content and the effect of the reduction in the titratable acidity of STPC that occurred during cold storage period may result in lower degree of lipid emulsification and higher fat leakage. Whereas, the lower titratable acidity may cause an adverse effect on the protein bonds and give a loss protein network, which leads to demulsify the fat and consequently makes it easy to release. Shimp (1985) confirmed that, as the cheese $\mathrm{pH}$ brought closer to 5.0, the proteins-protein bounds weaken and the fat start to demulsify. Similar findings were reported by Abd El-Salam et al. (1996 and 2005), Abd ElHamidet al. (2000) and Awad et al. (2003). 
TABLE 4. Textural profile analysis (TPA) of fresh STPC with different ratios of BRF in base blend.

\begin{tabular}{|c|c|c|c|c|c|c|}
\hline \multirow{2}{*}{ Property } & \multirow{2}{*}{$\begin{array}{c}\text { (control) } \\
\text { Nil }\end{array}$} & \multicolumn{5}{|c|}{ Ratio (\%) of BRF } \\
\hline & & 5 & 10 & 15 & 20 & 25 \\
\hline Hardness $(\mathrm{N})$ & $5.452^{\mathrm{d}}$ & $7.954^{c}$ & $10.958^{\mathrm{c}}$ & $12.959^{\mathrm{b}}$ & $14.962^{\mathrm{b}}$ & $16.965^{\mathrm{a}}$ \\
\hline Springingess (mm) & $19.99^{\mathrm{a}}$ & $19.81^{\mathrm{a}}$ & $19.13^{\mathrm{ab}}$ & $18.28^{\mathrm{ab}}$ & $17.43^{b}$ & $16.50^{\mathrm{b}}$ \\
\hline Gumminess (N) & $203.77^{d}$ & $521.31^{\mathrm{c}}$ & $788.18^{c}$ & $1053.63^{b}$ & $1367.68^{b}$ & $1783.23^{\mathrm{a}}$ \\
\hline Cohesiveness (ratio) & $37.376^{\mathrm{d}}$ & $65.541^{\mathrm{c}}$ & $71.927^{\mathrm{c}}$ & $81.305^{\mathrm{b}}$ & $91.410^{\mathrm{b}}$ & $105.112^{\mathrm{a}}$ \\
\hline Chewiness (N/mm) & $4073.441^{\mathrm{d}}$ & $10327.213^{c}$ & $15077.808^{c}$ & $19260.384^{b}$ & $23838.600^{b}$ & $29423.214^{\mathrm{a}}$ \\
\hline
\end{tabular}

The means with the same letter at any position did not significantly differ $(\mathrm{P}>0.05)$

$\mathrm{N}:$ Newton m: metre mm: millimetre

TABLE 5. Physical properties of STPC with different ratios of BRF in base blend, when fresh and during cold storage period $(\mathrm{CSP})$ at $5 \pm 1^{\circ} \mathrm{C}$.

\begin{tabular}{|c|c|c|c|c|c|c|c|}
\hline \multirow{2}{*}{ Property } & \multirow{2}{*}{$\begin{array}{c}\text { CSP } \\
\text { (months) }\end{array}$} & \multirow{2}{*}{$\begin{array}{c}\text { (control) } \\
\text { Nil }\end{array}$} & \multicolumn{5}{|c|}{ Ratio (\%) of BRF } \\
\hline & & & 5 & 10 & 15 & 20 & 25 \\
\hline \multirow{3}{*}{ Penetration (mm) } & Fresh & $30.1^{\mathrm{a}, \mathrm{a}}$ & $28.9^{\mathrm{b}, \mathrm{a}}$ & $27.8^{\mathrm{b}, \mathrm{a}}$ & $26.5^{\mathrm{c}, \mathrm{a}}$ & $25.00^{\mathrm{c}, \mathrm{a}}$ & $23.3^{\mathrm{d}, \mathrm{a}}$ \\
\hline & 1 & $28.0^{\mathrm{a}, \mathrm{b}}$ & $27.5^{\mathrm{b}, \mathrm{b}}$ & $26.4^{\mathrm{b}, \mathrm{b}}$ & $25.0^{\mathrm{c}, \mathrm{b}}$ & $23.4^{\mathrm{c}, \mathrm{b}}$ & $21.6^{\mathrm{d}, \mathrm{b}}$ \\
\hline & 3 & $26.6^{\mathrm{a}, \mathrm{c}}$ & $25.4^{\mathrm{b}, \mathrm{c}}$ & $25.0^{\mathrm{b}, \mathrm{c}}$ & $24.6^{\mathrm{b}, \mathrm{c}}$ & $24.3^{\mathrm{b}, \mathrm{c}}$ & $24.0^{\mathrm{c}, \mathrm{b}}$ \\
\hline \multirow{3}{*}{ Oil separation index } & Fresh & $12.5^{\mathrm{d}, \mathrm{c}}$ & $16.2^{\mathrm{c}, \mathrm{b}}$ & $20.1^{\mathrm{c}, \mathrm{b}}$ & $22.3^{\mathrm{b}, \mathrm{b}}$ & $20.1^{\mathrm{b}, \mathrm{b}}$ & $18.0^{\mathrm{a}, \mathrm{b}}$ \\
\hline & 1 & $13.2^{\mathrm{d}, \mathrm{b}}$ & $16.9^{\mathrm{c}, \mathrm{a}}$ & $20.4^{\mathrm{c}, \mathrm{a}}$ & $22.8^{\mathrm{b}, \mathrm{ab}}$ & $25.0^{\mathrm{b}, \mathrm{ab}}$ & $27.1^{\mathrm{a}, \mathrm{ab}}$ \\
\hline & 3 & $14.0^{\mathrm{d}, \mathrm{a}}$ & $17.1^{\mathrm{c}, \mathrm{a}}$ & $20.8^{\mathrm{c}, \mathrm{a}}$ & $23.4^{\mathrm{b}, \mathrm{a}}$ & $25.6^{\mathrm{b}, \mathrm{a}}$ & $27.5^{\mathrm{a}, \mathrm{a}}$ \\
\hline \multirow{3}{*}{ Meltability \% } & Fresh & $115^{\mathrm{a}, \mathrm{a}}$ & $105^{\mathrm{b}, \mathrm{a}}$ & $80^{\mathrm{b}, \mathrm{a}}$ & $60^{\mathrm{c}, \mathrm{a}}$ & $50^{\mathrm{c}, \mathrm{a}}$ & $40^{\mathrm{d}, \mathrm{a}}$ \\
\hline & 1 & $113^{\mathrm{a}, \mathrm{ab}}$ & $102^{\mathrm{b}, \mathrm{ab}}$ & $78^{\mathrm{b}, \mathrm{ab}}$ & $58^{\mathrm{c}, \mathrm{a}}$ & $48^{\mathrm{c}, \mathrm{a}}$ & $39^{\mathrm{d}, \mathrm{a}}$ \\
\hline & 3 & $109^{\mathrm{a}, \mathrm{b}}$ & $98^{\mathrm{b}, \mathrm{b}}$ & $76^{\mathrm{b}, \mathrm{b}}$ & $55^{\mathrm{c}, \mathrm{a}}$ & $46^{\mathrm{c}, \mathrm{a}}$ & $38^{\mathrm{d}, \mathrm{b}}$ \\
\hline
\end{tabular}

The letters before comma possess the factor of the manufacture of cheese-base with ratio (\%) of BRF. While those after comma possess the factor of the cold storage period. The means with the same letter at any position did not significantly differ $(\mathrm{p}>0.05)$.

Opposite to the oil separation index, the meltability \% of STPC was lowered whether as the cheese-base was manufactured with BRF and the effect of the cold storage period progressed. Shimp (1985) mentioned that, as the cheese $\mathrm{pH}$ was brought closer to 5.0, the texture could become crumbly because the protein-protein bounds weaken. Cavalier-Salou and Cheftel (1991) reported that, the melting ability was correlated to high $\mathrm{pH}$, soft texture and high degree of casein dissociation.

\section{Organoleptic properties}

The sensory evaluation of STPC samples with different ratio of BRF in the base blend and the effect of the cold storage period for three months, is shown in Table 6. The obtained data indicated that, the use of BRF instead of cheese- 
base did not lead to any significant differences in the score of all organoleptic attributes judged in STPC. Moreover, no significant differences between all blends in flavour and aroma even after storage period. On the other hand significant decrease was noticed in the control treatment after three months compared to all treatments except the treatment excluded by replacing $25 \%$. Also, Table 6 revealed that the black rice flavour was accepted and flavorably preferred in STPC. The overall panelist scores confirm the previous observations regarding the different or organoleptic criteria. Furthermore, black rice improved the STPC ability to keep its sensory quality along the cold storage period.

\section{Conclusion}

As a conclusion, the foregoing results led to conclude that, STPC can be made with replacing $20 \%$ of BRF in the formulation with cheese-base. Higher percentages of substitution than $20 \%$ decreased the acceptability of the product.

TABLE 6. Organoleptic scores of STPC with different ratios of BRF in base blend, when fresh and during cold storage period (CSP) at $5 \pm 1^{\circ} \mathrm{C}$.



The letters before comma possess the factor of the manufacture of cheese-base with ratio (\%) of BRF. While those after comma possess the factor of the cold storage period. The means with the same letter at any position did not significantly differ $(\mathrm{p}>0.05)$.

\section{References}

Abdel-Aal, E.S., Young, J.C. and Rabalski, L. (2006) Anthocyanin composition in black, blue, pink, purple and red cereal grains. J. Agric. Food Chem. 54, 4696-4704.

Abd El-Hamid, L.B., El-Shabrawy, S.A., Awad, R.A. and Singh, R.K. (2000) Chemical properties of Ras cheese spreads as affected by emulsifying salt mixtures. J. Food Processing Preservation, 24,191-208.

Abd El-Salam, M. H., El-Shibiny, S. and Ahmed, N. S.(2005) Studies on processed cheese spreads in Egypt. Areview. Egypt. J. Dairy Sci. 33,129-141.

Abd El-Salam, M. H., Al-Khamy, A.F., El-Garawany, Egypt. J. Food Sci. 46 (2018)
G.A., Hamed, A. and Khader, A. (1996) Composition and rheological properties of processed cheese spread as affected by the level of added whey protein concentrates and emulsifying salt. Egypt. J. Dairy Sci. 24, 309-322.

Association of Official Analytical Chemists (AOAC) (2007) Official Methods of Analysis.Dairy Products, Gaithersburg, Maryland, USA; subchapter $8.18^{\text {th }}$ ed., pp.802-850.Benjamin Franklin Stationary Washington, D. C. USA.

Awad, R.A., Farahat, Azza M. and El-Batawy, O.I. (2014) Impact of Jerusalem artichoke puree as a cheese base replacement in the manufacture of processed cheese. Egypt. J. Food Sci., 42, 55-70. 
Awad, R.A. and Salama, Wafaa M. (2010) Development of a novel processed cheese product containing fermented barley. Egyptian J. Dairy Sci. 38, 95-103.

Awad, R.A., Abd El-Hamid, L.B., El-Shabrawy, S.A. and Singh, R. K. (2003) Texture and microstructure of block type processed cheese with formulated emulsifying salt mixtures. Lebensmitte L-wissenschaft-Und-Technol. 35, 45-61.

Berger, W., Klostermeyer, H., Merkenicl, K. and Uhlmann, G. (1989) In: Processed Cheese Manufacture. A Joha ${ }^{\circledR}$ Guide BK Ladenburg Gmb H, Gesellschaftfuerchemische Erzeugnisse, Ladenburg, Germany.

Bourne, M.C. (1982) Food Texture and Viscosity Concept and Measurement. pp. 544-546. Academic Press Inc., New York, USA.

Caric, M. and Kalab, M. (1993) Processed Cheese Products. In: Cheese Chemistry Physics, and Microbiology, pp. 467-505. $2^{\text {nd }}$ ed, by Fox, P.F., Major Cheese groups, Chapman Ha11Ltd, London, UK.

Cavalier-Salou, C. and Cheftel, J.C. (1991) Emulsifying salts influence on characteristics of cheese analogs from calcium casein ate. J. Food Sc., 56, 1542-1547.

CFI (2015) Chamber of Food Industries. Annual Report, Cairo.

Chen, P.N., Kuo, W.H., Chiang, C.L., Chiou, H.L., Hsieh, Y.S. and Chu, S.C. (2006) Black rice anthocyanins inhibit cancer cells invasion via repressions of MMPs and u. PA expression. Chem. Biol. Interact. 163 (3), 218-229.

Elfalleh, W., Nasri, N., Marzougui, N., Thabti, I. and Mrabet, A. (2009) Physico-chemical properties and DPPH-ABTS Scavenging activity of some ocal pomegranate (Punicagranatum) ecotypes. Int. J. Food Sci., Nutri. 60,197-210.

Fayed, A.E., Farahat, Azza M. and Mohamed, Ragia O. (2009) Utilization of mushroom powder for substituting dried skim milk in the manufacture of processed cheese spread. Egypt. J. Agric. Res. 87 (2), 509-521.

Fox, P.F., Guince, T.P., Cogan, T.M. and McSweeny, P.L.H. (2000) Fundamentals of Cheese Science. pp. 429-451. Aspen Publ., Inc., Gaithersburg, Maryland, USA.

Fox, P.F., Guince, T.P., Cogan, T.M. and McSweeny, P.L.H. (2000) Cheese rheology and texture.In:
Fundamentals of Cheese Science.Aspen Publishers, Inc., Gaithersburg. MD, pp. 305-333.

Giusti, M.M. and Wrolstad, R.E. (2005) Characterization and Measurement of Anthocyanins by UV-Visible Spectroscopy- In: Hand book of Food Analytical Chemistry, Water, Proteins, Enzymes, Lipids and Carbohydrates, Wrolstad, R.E., E.A.Decker, S.J.Schwartz and P. Sporns (Ed.). John Wiley and Sons, New York, ISBN: 9780471709091, pp:19-31.

Guo, H., Ling, W., Wang, Q., Liu, C. and Hu, Y. (2007) Effect of anthocyanin-rich extract from black rice (Oryza sativa L. indica) on hyper lipidemia and insulin resistance in fructose-fedrats. Plant Foods Hum. Nutr. 62, 1-6.

Hosseinian, F.S., Li, W. and Beta, T. (2008) Measurement of anthocyanins and other phytochemicals in purple wheat. Food Chem. 109, 916-924.

Hu, C., Zowistowski, J., Ling, W.H. and Kitts, D.D. (2003) Black rice (Oryza sativa L. indica) pigmented fraction suppresses both reactive oxygen species and nitric oxide in chemical and biological model system. J. Agric. Food Chem. 51, 5271-5277.

Karan, G.S. and Ak, M.M. (2003) Cheese Rheology and Texture. pp. 299-375. CRC Press LLC, Washington, D.C., USA.

Li, H., Prakash, S., Nicholson, T.M., Fitzgerald, M.A. and Gilbert, R.G. (2016) The importance of amylase and amylopectin fine structure for textural properties of cooked rice grains. Food Chemistry, 196, 702-711.

Ling, E.R. (1963) A text Book of Dairy Chemistry. Vol. II Practical Chapman and Hall, Ltd, London.

Ling, W.H., Chang, Q.X., Ma, J. and Wang, T. (2001) Red and black rice decrease atherosclerotic plaque formation and increase antioxidant status in eabbits, J. Nutr. 131,1421-1426.

Ling, W.H., Wang, L.L. and Ma, J. (2002) Supplementation of the black rice outer layer fraction to rabbits decreases atherosclerotic plaque formation and increases antioxidant status. J. Nutr. 132, 20-26.

Mahran, G.A., Fayed, A.E.,Youssef, M.H. and Negm, M.S. (2007) Utilization of ultrafiltrated whey protein concentrate in the manufacture of reduced fat processed cheese spread. J. Biol. Chem. Environ. 
Sci., 2, 137-151.

Meyer, A. (1973) Processed Cheese Manufacture. pp. 30-276. $1^{\text {st }}$ ed. Food Trade Press. Ltd., London, UK.

Nasri, N., Tlili, N., Elfalleh, W., Cherif, E., Ferchichi, A., Khaldi, A. and Triki, S. (2011) Chemical compounds from Phoenician juniper berries (Juniperus phoenicea). Nat. Prod. Res. 25, 1733-1742.

Okonogi, S., Duangrat, C., Anuchpreeda, S., Tachakittirungrod, S. and Chowwanapoonpohn, S. (2007) Comparison of antioxidant capacities and cytotoxicities of certain fruit peels. Food Chem. 103, 839-846.

Pollard, A., Sherkat, F., Seuret, M.G. and Halmos, A.L. (2003) Textural changes of natural Cheddar cheese during the maturation process. J. Food Sci. 68, 2011-2016.

S A S (1998) Statistical Analysis System. SAS User's Guide : Statistics SAS Inst. Inc. Ed., Cary, NC. USA.

Shimp, L.A. (1985) Processed cheese principles. Food Tech. 39, 63-70.

Suzuki, M., Kimura, T., Yamagishi, K., Shinmoto, H. and Yamaki, K. (2004) Comparison of mineral contents in 8 cultivars of pigmented brown rice. Nippon Shokuhin Kagaku KogakuKaishi, 51 (8), 424-427.

Tamime, A,Y., Kalab, M., Davies, G. and Youns, M. F. (1990) Microstructure and firmness of processed cheese manufactured from Cheddar cheese and skim milk powder cheese base. Food Microstructure, 9, 23.
Tawfek, Meranda, A., Mohamed, Zahrat El-Ola, M. and Rizk, Ayat, E. (2017) Partial substitution of non fat milk solids with dehulled black rice flour in ice milk manufacture. Egypt. J. Agric. Res., 95 (2),787-801.

Thomas, M.A. (1977) The Processed Cheese Industy. $1^{\text {st }}$ ed., Series, Bull. (New South Wales. Dept. of Agric., D44). Joseph Vogele Co., Germany.

Thomas, M.A. (1973). The use of hard milk fat fraction in processed cheese. Aust. J. Dairy Technol. 28, 7780.

Xia, M., Ling, W.H., Kitts, D. and Zawistowski, J. (2003) Supplementation of diets with black rice pigment fraction attenuates atherosclerotic plaque formation in apolipoprotein Edeficient mice. $J$. Nutr. 133, 44-751.

Younis, M.F., Tamime, A.Y., Davies, G., Hunter, E.A. and Abd El-Hady, S. M. (1991) Production of processed cheese using Cheddar cheese and cheese base.5-rheological properties. Milchwissenschfat 46, 701-705.

(Received:17 / 1/2018; accepted:6/2/2018) 


\title{
تأثير اضافة دقيق الارز الاسود علي خواص مفرود الجبن المطبوخ
}

\author{
مير اندا عبد المجلي توفيق تئي \\ قسم بحوث تكنولزجيا تصنيع الالبان- معهد بحوث تكنولوجيا الأغذية ـ مركز البحوث الزر اعية ـالجيزة ـ مصر
}

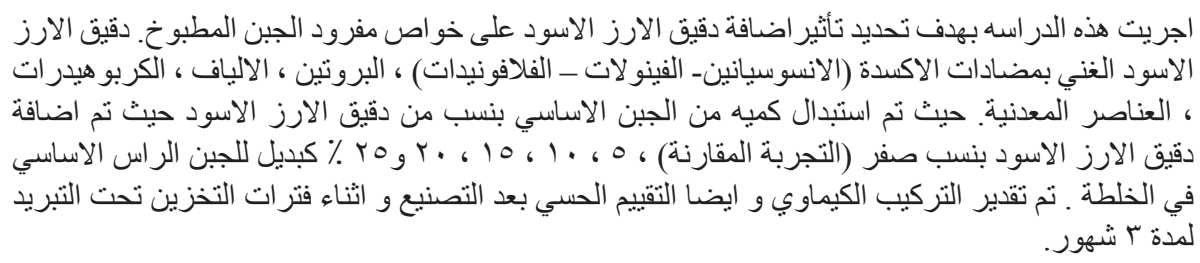

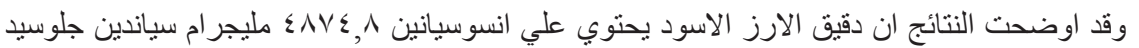

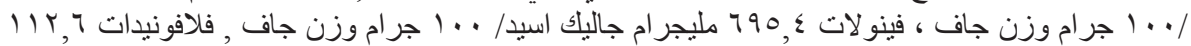

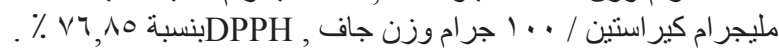

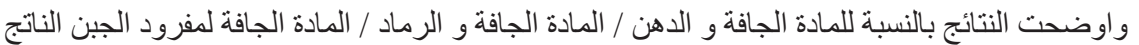









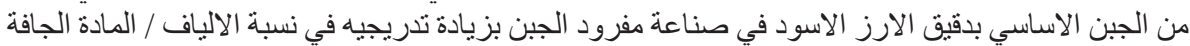

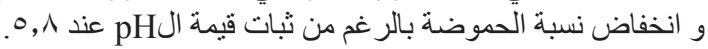



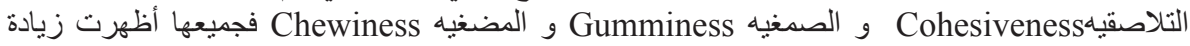

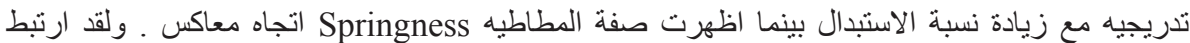

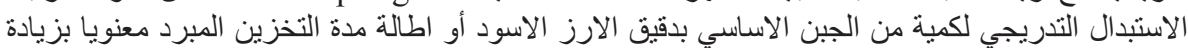

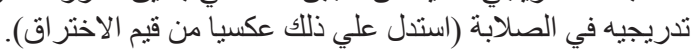

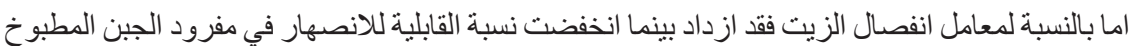

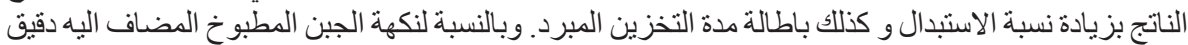

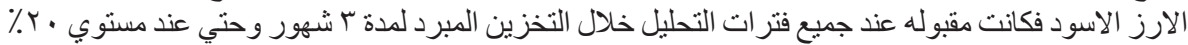
استبدال من كمية الجبن الاساسي.

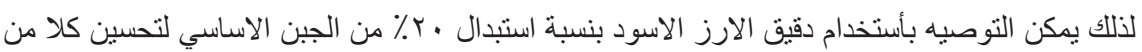

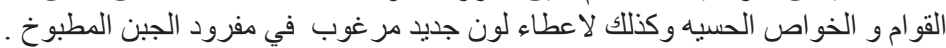

